\title{
Pumilacidins A-E from Sediment-Derived Bacterium Bacillus sp. 4040 and Their Antimicrobial Activity Evaluation
}

\author{
Josiane A. M. de Oliveira, ${ }^{a, b}$ David E. Williams, ${ }^{b}$ Raymond J. Andersen, ${ }^{b}$ \\ Maria H. Sarragiotto ${ }^{*, a}$ and Debora C. Baldoqui ${ }^{\circledR}, a$ \\ ${ }^{a}$ Departamento de Química, Universidade Estadual de Maringá, \\ Av. Colombo 5790, 87020-900 Maringá-PR, Brazil \\ ${ }^{b}$ Department of Chemistry and Earth, Ocean and Atmospheric Sciences, \\ University of British Columbia, V6T 1 Z1 Vancouver, B.C., Canada
}

\begin{abstract}
Marine strains of Bacillus are known to produce secondary metabolites different from that accumulated by their terrestrial counterparts, for example, lipopeptides such as surfactins, iturins and fengycins, which exhibit a variety of biological activities. Another important class of lipopeptides are pumilacidins, identified specially from Bacillus pumilus strains, usually by using liquid chromatography-mass spectrometry (LC-MS) techniques. In this work, five knowns pumilacidins were isolated from the solid culture of the marine-derived bacterium Bacillus sp. 4040. The structures of compounds, pumilacidins A-E, were determined using a combination of mass spectrometry, nuclear magnetic resonance (NMR) spectroscopy and comparison with reported data. The ${ }^{1} \mathrm{H}$ and ${ }^{13} \mathrm{C}$ NMR data of pumilacidin $\mathrm{B}$ is being described here for the first time. All compounds were evaluated against five microorganisms, but no antimicrobial activity was detected.
\end{abstract}

Keywords: Bacillus sp., cyclic lipopeptides, pumilacidins, antimicrobial activity

\section{Introduction}

Bacillus genus belongs to Bacillaceae family, and constitute the largest, most diverse and most prominent genus of aerobic endospore-forming bacteria, with more than 260 species. ${ }^{1}$ Species and strains of this genus are known to produce secondary metabolites with antifungal and antibacterial activities against different phytopathogens. Also, they grow rapidly in liquid culture, producing extremely resistant spores, with high thermal tolerance, which makes these bacteria ideal candidates for use as biological control agents., ${ }^{2,3}$

Marine strains of Bacillus usually produce secondary metabolites which are not found in their terrestrial counterparts, ${ }^{4}$ as for example, lipopeptides, polypeptides, macrolactones, fatty acids, polyketides and isocoumarins, ${ }^{4}$ many of them exhibiting a wide range of biological properties, such as antibiotic, anticancer and antifungal activities. ${ }^{3,4}$

Natural peptides have attracted attention because of their promising applicability as pharmaceuticals and/or

*e-mail: mhsarragiotto@uem.br; dcbaldoqui@uem.br as templates for therapeutics. ${ }^{5}$ Surfactins, iturins and fengycins are lipopeptides commonly found in Bacillus, which exhibit a variety of biological activities, ${ }^{6}$ including antifungal, anti-inflammatory, antiviral, and antiplatelet properties, besides to show interactions with biofilms. ${ }^{7-9}$

Pumilacidins are a variant of the surfactin family, and were described for the first time by Naruse et al. ${ }^{10}$ from a culture of Bacillus pumilus. The structures of these compounds were stablished by hydrolysis and analysis of the amino acid residues by cation exchange resin chromatography. The amino acids configurations were determined by their specific optical rotations. This class of lipopeptides are often detected in Bacillus pumilus culture, usually by using liquid chromatography-mass spectrometry (LC-MS) techniques. ${ }^{11-16}$

The potential of Bacillus species as promising sources of structurally diverse and bioactive compounds led us to investigate the chemical composition and biological activity of the sediment-derived bacterium Bacillus sp. 4040 isolates. In this paper, we describe the isolation and structural elucidation of five known pumilacidins 1-5 (Figure 1) from the Bacillus sp. 4040 isolates, as well as the evaluation of their antimicrobial activity against $P$ seudomonas aeruginosa, 
Escherichia coli, methicillin resistant Staphylococcus aureus, Bacillus subtilis and Candida albicans. Also, a complete assignment of ${ }^{1} \mathrm{H}$ and ${ }^{13} \mathrm{C}$ nuclear magnetic resonance (NMR) spectral data of cyclic lipopeptides pumilacidins A (1) and B (2) was carried out.

\section{Experimental}

\section{General experimental procedures}

Low- and high-resolution MS were recorded using electrospray (ESI) ionization and a time-of-flight (TOF) mass analyzer. The ${ }^{1} \mathrm{H}$ and ${ }^{13} \mathrm{C}$ NMR spectra were recorded on a Bruker AV-600 spectrometer with a $5 \mathrm{~mm}$ CPTCI cryoprobe. ${ }^{1} \mathrm{H}$ chemical shifts are referenced to the deutered dimethyl sulfoxide (DMSO- $d_{6}$ signal $(\delta 2.49 \mathrm{ppm})$ and ${ }^{13} \mathrm{C}$ chemical shifts are referenced to the DMSO- $d_{6}$ solvent peak $(\delta 39.5 \mathrm{ppm})$. Merck Type 5554 silica gel plates and Whatman MKC18F plates were used for analytical thin layer chromatography. High-performance liquid chromatography (HPLC) purifications were performed on a Waters 1525 binary HPLC pump attached to a photodiode array detector (PDA) Waters model 2998 with scan between $\lambda_{\max } 200$ and
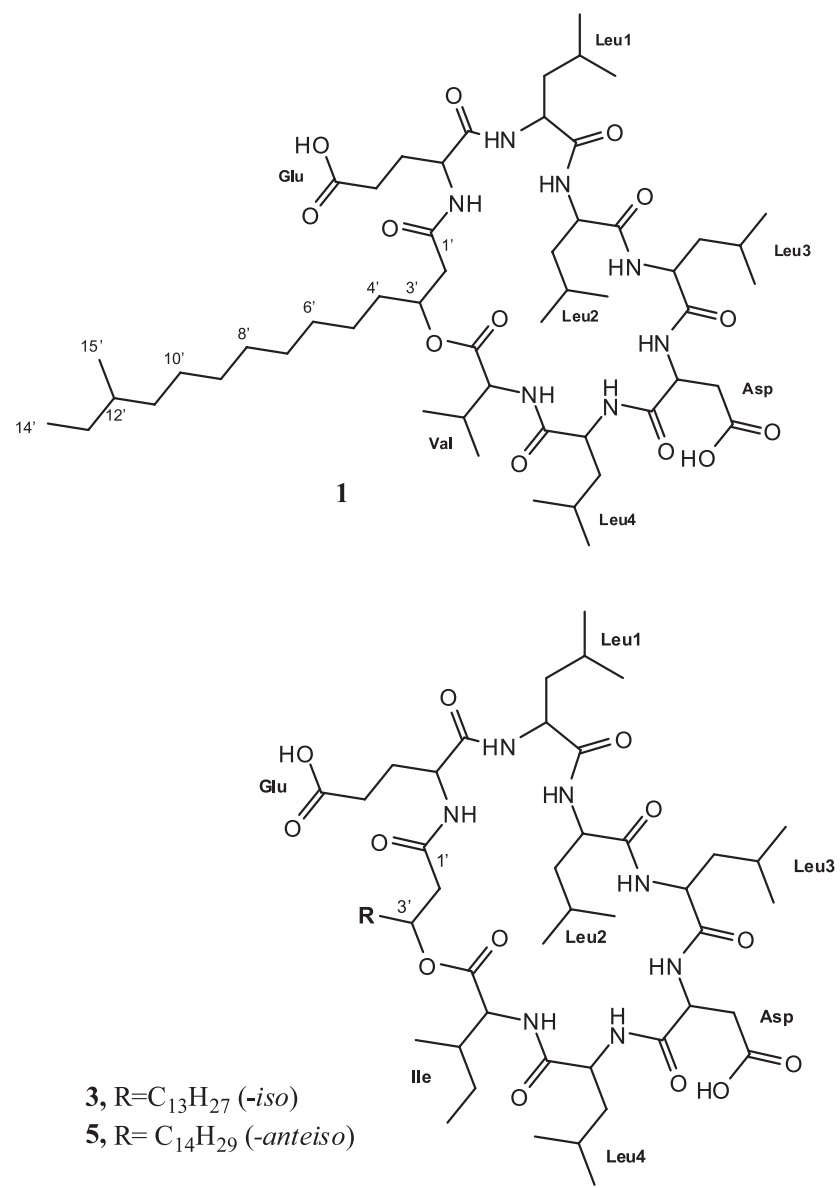

Figure 1. Structures of cyclic lipopeptides isolates from Bacillus sp. 4040.
$400 \mathrm{~nm} . \mathrm{A} \mathrm{C}_{18}$ reversed-phase InertSustain, $10 \times 250 \mathrm{~mm}$, $5 \mu \mathrm{m}$ column manufactured in Japan was used for HPLC purifications. All solvents used for HPLC were HPLC grade. Optical rotations were measured using a Jasco P-1010 Polarimeter with sodium light (589 nm).

\section{Bacteria material and cultivation condition}

Bacillus sp. 4040 was isolated from a marine sediment collected in the Strait of Georgia between Vancouver and Vancouver Island in February $2010\left(49^{\circ} 28.706^{\prime} \mathrm{N}\right.$, $123^{\circ} 56.377^{\prime} \mathrm{W}$ ) at the depth of $143 \mathrm{~m}$. The active isolate was cultured in containers containing approximately $350 \mathrm{~mL}$ of the autoclaved marine medium 1 (10 g of soluble starch, $4 \mathrm{~g}$ of yeast extract, $2 \mathrm{~g}$ of peptone, $0.001 \mathrm{~g}$ of $\mathrm{FeSO}_{4} .7 \mathrm{H}_{2} \mathrm{O}, 0.001 \mathrm{~g}$ of $\mathrm{KBr}, 18 \mathrm{~g}$ of agar, $1 \mathrm{~L}$ of sea water) at room temperature for 14 days. The mature cultures were cut into small squares containing the bacterial biomass and medium, according to methodology described and adapted by Dalisay et al. ${ }^{17}$ The identification of the bacteria was made by Jessie Chen of the UBC Biological Services Laboratory. Sequences of the $16 \mathrm{~S}$ ribosomal ribonucleic acid (rRNA) gene from the 4054 bacteria were examined<smiles>CCC(C)CCCCCCCCCC(CC(=O)NC(CCC(=O)O)C(=O)NC(CC(C)C)C(=O)NC(CC(C)C)C(=O)NC(CC(C)C)C(=O)NC(CC(=O)O)C(=O)NC(CC(C)C)C(=O)NC(C(=O)O)C(C)CC)OC(=O)C(CC(C)C)NC(=O)C(C)C</smiles>

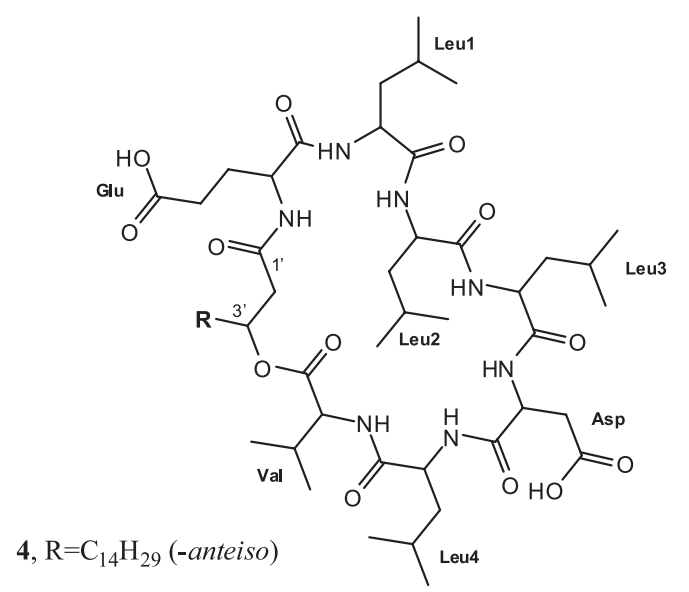


by phylogenetic analysis. Comparative research using the BLASTn program ${ }^{18}$ of the gene sequences found that the bacterium belonged to the genus Bacillus, according to the Genbank database, ${ }^{19}$ with $98 \%$ similarity index (NCBI Accession No. KY476210.1). A voucher specimen (No. RJA4040) was deposited in Bioservices at University of British Columbia (Vancouver) and a sample of the bacteria is kept in a freezer at $-80^{\circ} \mathrm{C}$.

\section{Extraction and isolation}

The solid agar cultures were extracted repeatedly with EtOAc. Concentration of the $5 \mathrm{~L}$ of combined EtOAc extracts in vacuo gave a gummy brown residue that was partitioned between EtOAc $(3 \times 80 \mathrm{~mL})$ and $\mathrm{H}_{2} \mathrm{O}$ $(20 \mathrm{~mL})$. The combined EtOAc extract was concentrated under reduced pressure to give a brown solid $(185.0 \mathrm{mg})$, and this residue was fractionated on Sephadex LH-20 using $\mathrm{CH}_{2} \mathrm{Cl}_{2} / \mathrm{MeOH}(2: 8)$ as eluent to afford eight subfractions (4040-F1 to 4040-F4). The subfraction 4040-F1 (100.2 mg) was chromatographed on a Sep Pak ${ }^{\circledR}$ vac $12 \mathrm{cc}$ prepackaged column ( $2 \mathrm{~g}$, silica) using hexane, ethyl acetate and methanol as the eluent, in increasing order of polarity to give new four subfractions. The subfraction 4040-F1J3 (49.5 mg) was purified by $\mathrm{C}_{18}$ reversedphase HPLC (InertSustain $5 \mu \mathrm{m}, 250 \times 10 \mathrm{~mm}$ ) with $\mathrm{MeCN} / \mathrm{H}_{2} \mathrm{O}(9: 1)$ and $0.05 \%$ trifluoroacetic acid (TFA) as eluent to give pure samples of $\mathbf{1}$ (6.5 mg), 2 (10.2 mg), 3 $(1.5 \mathrm{mg}), \mathbf{4}(2.0 \mathrm{mg})$ and $\mathbf{5}(3.9 \mathrm{mg})$, in that order.

\section{Pumilacidin B (1)}

White amorphous solid; $[\alpha]_{\mathrm{D}}^{23}-10.0(c 4.0, \mathrm{MeOH})$; high resolution mass spectrometry electrospray ionization timeof-flight (ESITOFHRMS) $\mathrm{m} / z$, calcd. for $\mathrm{C}_{53} \mathrm{H}_{94} \mathrm{~N}_{7} \mathrm{O}_{13} \mathrm{H}$ $[\mathrm{M}+\mathrm{H}]^{+}:$: 1036.6910 , found: $1036.6946 ;{ }^{1} \mathrm{H}$ and ${ }^{13} \mathrm{C}$ NMR: see Table 1 .

\section{Pumilacidin A (2)}

White amorphous solid; $[\alpha]_{\mathrm{D}}^{23}-10.1($ c 6.0, MeOH); ESITOFHRMS $m / z$, calcd. for $\mathrm{C}_{54} \mathrm{H}_{95} \mathrm{~N}_{7} \mathrm{O}_{13} \mathrm{Na}[\mathrm{M}+\mathrm{Na}]^{+}$: 1072.6886, found: $1072.6896 ;{ }^{1} \mathrm{H}$ and ${ }^{13} \mathrm{C}$ NMR: see Table 2 .

\section{Pumilacidin E (3)}

White amorphous solid; $[\alpha]_{\mathrm{D}}^{23}-16.7$ (c 0.3, MeOH); ESITOFHRMS $m / z$, calcd. for $\mathrm{C}_{55} \mathrm{H}_{97} \mathrm{~N}_{7} \mathrm{O}_{13} \mathrm{Na}[\mathrm{M}+\mathrm{Na}]^{+}$: 1086.7042, found: 1086.7053 ; see ${ }^{1} \mathrm{H}$ NMR spectrum in Supplementary Information (SI) section.

Pumilacidin D (4)

White amorphous solid; $[\alpha]_{\mathrm{D}}^{23}-10.1$ (c 1.0, MeOH);
ESITOFHRMS $m / z$, calcd. for $\mathrm{C}_{55} \mathrm{H}_{97} \mathrm{~N}_{7} \mathrm{O}_{13} \mathrm{Na}[\mathrm{M}+\mathrm{Na}]^{+}$: 1086.7042, found: 1086.7045 ; see ${ }^{1} \mathrm{H}$ NMR spectrum in SI section.

\section{Pumilacidin C (5)}

White amorphous solid; $[\alpha]_{\mathrm{D}}^{23}-9.8($ c 3.3, MeOH); ESITOFHRMS $m / z$, calcd. for $\mathrm{C}_{56} \mathrm{H}_{99} \mathrm{~N}_{7} \mathrm{O}_{13} \mathrm{Na}[\mathrm{M}+\mathrm{Na}]^{+}$: 1100.7199, found: 1100.7197 ; see ${ }^{1} \mathrm{H}$ NMR spectrum in SI section.

\section{Antimicrobial assay}

The experimental procedures were performed following an agar-diffusion test protocol. ${ }^{17}$ The extract of Bacillus sp. 4040 and the compounds (1-5) were evaluated against the microorganisms Pseudomonas aeruginosa ATCC 27853, Escherichia coli UBC 8161, methicillin resistant Staphylococcus aureus MRSA, ATCC33591, Bacillus subtilis H344 and Candida albicans ATCC 90028. The extract and the compounds were delivered on a sterile blank disk at $40 \mu \mathrm{g}$ per disk. The zone of inhibition of the extract was measured in mm and compared to the positive controls: rifamycin (10 $\mu \mathrm{g}$ per disk) and ampothericin B (20 $\mu \mathrm{g}$ per disk) and as negative control DMSO. The plates were incubated for 18 to $24 \mathrm{~h}$ at room temperature and the diameters of inhibition halos were obtained with the aid of a caliper.

\section{Results and Discussion}

Compound $\mathbf{1}$ was obtained as a white solid, $[\alpha]_{\mathrm{D}}^{23}-10.0$ (c 4.0, MeOH). ${ }^{1} \mathrm{H}$ NMR analysis showed the presence of seven signals at $\delta_{\mathrm{H}} 7.66(\mathrm{~d}, 8.4 \mathrm{~Hz}), 7.84(\mathrm{~d}$, $6.6 \mathrm{~Hz}$ ), 7.97 (bs), 8.01 (d, 6.6 Hz), 8.10 (d, 7.2 Hz), 8.14 $(\mathrm{m})$ and $8.16(\mathrm{~m})$ assigned to the seven $\mathrm{NH}$ groups. In addition, it was observed signals at $\delta_{\mathrm{H}} 4.45,4.44,4.20$, $4.15,4.14,4.09$ and 4.05, assigned to the $\alpha$-hydrogen, which evidenced the presence of 7 amino acid units. A fatty acid chain was evidenced by multiplets in the region between $\delta_{\mathrm{H}} 1.50$ and $\delta_{\mathrm{H}} 1.18$, and the signals at $\delta_{\mathrm{H}} 4.97$ $(1 \mathrm{H}, \mathrm{m})$ and $\delta_{\mathrm{H}} 2.38(2 \mathrm{H}, \mathrm{m})$ were attributed to the $\mathrm{H}-3$ ' and $\mathrm{H}-2$ ', respectively.

The signals at $\delta_{\mathrm{C}} 174.0$ and $\delta_{\mathrm{C}} 169.6$ in the ${ }^{13} \mathrm{C}$ NMR spectrum were attributed to the carboxylic acid of glutamic acid (Glu) and to C-1', respectively. The other characteristic carbonyl signals at $\delta_{\mathrm{C}} 172.2,172.1,171.8,171.7,171.1$, 170.7 and 170.0 were assigned to the seven amino acids present in this molecule. Signals between $\delta_{\mathrm{C}} 33.3$ and 11.2 were attributed to the fatty acid portion, and two methyl groups were evidenced at $\delta_{\mathrm{C}} 19.2$ and 11.2, which are characteristic of anteiso form. 
From the gHMBC spectrum, it was possible to verify the connectivity of the amino acids especially by the correlations of the $\alpha$-hydrogens of the amino acids with the carbonyl group of the adjacent amino acid residue. The correlations between $\delta_{\mathrm{H}} 4.97\left(\mathrm{H}-3^{\prime}\right)$ and $\delta_{\mathrm{C}} 170.7$ (C-1-Val, Val: valine), 169.6 (C-1') and 24.2 (C-4-Leu2, Leu: leucine) and $\delta_{\mathrm{H}} 2.38\left(\mathrm{H}-2^{\prime}\right)$ with $\delta_{\mathrm{C}} 169.6\left(\mathrm{C}-1^{\prime}\right), 71.6\left(\mathrm{C}^{\prime} 3^{\prime}\right)$ and 33.3 (C-4') permitted to established the linkage between the depsipeptide cycle with the $\beta$-hydroxy fatty acid.

Analysis of the correlation spectroscopy (COSY), heteronuclear multiple bond correlation (HMBC), total correlation spectroscopy (TOCSY) and rotating-frame overhauser effect spectroscopy (ROESY) correlations between adjacent residues enabled us to establish the sequence of $\mathbf{1}$ as Glu-Leu1-Leu2-Leu3-Asp-Leu4-Val and a $\beta$-amino fatty acid chain (Table 1 ). The main $\mathrm{HMBC}$, COSY and ROESY correlations are illustrated in Figure 2.

The ESITOFHRMS spectra showed a pseudo-molecular ion peak $m / z$ 1036.6946 $[\mathrm{M}+\mathrm{H}]^{+}$(calcd. for $\mathrm{C}_{53} \mathrm{H}_{94} \mathrm{~N}_{7} \mathrm{O}_{13} \mathrm{H}$,

Table 1. ${ }^{1} \mathrm{H}$ and ${ }^{13} \mathrm{C}$ NMR data for pumilacidin B (1) in $600 \mathrm{MHz}$, DMSO- $d_{6}$

\begin{tabular}{|c|c|c|c|}
\hline Position & No. & $\delta_{\mathrm{C}} / \mathrm{ppm}$ & $\delta_{\mathrm{H}} / \mathrm{ppm}($ mult., $J / \mathrm{Hz})$ \\
\hline & 1 & 171.1 & - \\
\hline & 2 & 52.1 & $4.15(\mathrm{~m})$ \\
\hline & 3 & 27.4 & $1.70 / 1.87(\mathrm{~m})$ \\
\hline \multirow[t]{7}{*}{ Glu } & 4 & 30.0 & $2.18(\mathrm{t}, 7.8)$ \\
\hline & 5 & 174.0 & - \\
\hline & $\mathrm{NH}$ & & $7.84(\mathrm{~d}, 6.6)$ \\
\hline & $-\mathrm{OH}$ & & \\
\hline & 1 & 172.2 & - \\
\hline & 2 & 51.9 & $4.14(\mathrm{~m})$ \\
\hline & 3 & 39.7 & $1.46(\mathrm{~m})$ \\
\hline \multirow[t]{7}{*}{ Leu-1 } & 4 & 24.4 & $1.46(\mathrm{~m})$ \\
\hline & 5 & 23.0 & $0.79(\mathrm{~m})$ \\
\hline & 6 & 22.5 & $0.79(\mathrm{~m})$ \\
\hline & $\mathrm{NH}$ & & 7.97 (bs) \\
\hline & 1 & 172.1 & - \\
\hline & 2 & 51.8 & $4.09(\mathrm{~m})$ \\
\hline & 3 & 39.7 & $1.49(\mathrm{~m})$ \\
\hline \multirow[t]{7}{*}{ Leu-2 } & 4 & 24.2 & $1.49(\mathrm{~m})$ \\
\hline & 5 & 23.0 & $0.79(\mathrm{~m})$ \\
\hline & 6 & 22.6 & $0.79(\mathrm{~m})$ \\
\hline & $\mathrm{NH}$ & & $8.16(\mathrm{~m})$ \\
\hline & 1 & 171.8 & - \\
\hline & 2 & 51.3 & $4.20(\mathrm{~m})$ \\
\hline & 3 & 40.8 & $1.38(\mathrm{~m})$ \\
\hline \multirow[t]{4}{*}{ Leu-3 } & 4 & 23.9 & $1.53(\mathrm{~m})$ \\
\hline & 5 & 21.7 & $0.77(\mathrm{~m})$ \\
\hline & 6 & 23.2 & $0.82(\mathrm{~m})$ \\
\hline & $\mathrm{NH}$ & & $8.01(\mathrm{~d}, 6.6)$ \\
\hline
\end{tabular}

1036.6910), which was consistent with the proposed structure. Based on these data, compound 1 was identified as pumilacidin $\mathrm{B}$, and the ${ }^{1} \mathrm{H}$ and ${ }^{13} \mathrm{C}$ NMR data of $\mathbf{1}$ is being described here for the first time.

Compound 2 was obtained as a white solid, $[\alpha]_{D}^{23}-10.1$ (c 6.0, $\mathrm{MeOH}$ ). ${ }^{1} \mathrm{H}$ and ${ }^{13} \mathrm{C}$ NMR analyses showed that this compound had similar structure to pumilacidin B (1). However, it was noted the absence of the signal at $\delta_{\mathrm{C}} 18.1$ attributed to the valine residue in compound $\mathbf{1}$, as well as the presence of additional signals at $\delta_{\mathrm{C}} 11.2$ and at $\delta_{\mathrm{C}} 15.5$. These data, together with the analysis of gHSQC, gHMBC, COSY and TOCSY spectra showed that compound $\mathbf{2}$ has an isoleucine residue at position 7. From the gHMBC data it was possible to prove that this amino acid was connected in the same part of the cycle by the correlations between the signal at $\delta_{\mathrm{H}} 8.14$ (NH-Ile, Ile: isoleucine) with at $\delta_{\mathrm{C}} 171.8$ (C-1-Leu4), and at $\delta_{\mathrm{H}} 4.95$ (H-2') with the signals at $\delta_{\mathrm{C}} 170.7$ (C-1-Ile) and 169.5 (C-1'). The sequence of amino acid in compound $\mathbf{2}$ was stablished as

\begin{tabular}{|c|c|c|c|}
\hline Position & No. & $\delta_{\mathrm{C}} / \mathrm{ppm}$ & $\delta_{\mathrm{H}} / \mathrm{ppm}$ (mult., $\left.J / \mathrm{Hz}\right)$ \\
\hline \multirow{5}{*}{ Asp } & 1 & 170.0 & - \\
\hline & 2 & 49.7 & $4.45(\mathrm{~m})$ \\
\hline & 3 & 36.0 & $\begin{array}{c}2.64(\mathrm{dd}, 4.8 .17 .4) / 2.56(\mathrm{dd}, 9.0 . \\
16.2)\end{array}$ \\
\hline & 4 & 171.7 & - \\
\hline & $\mathrm{NH}$ & & $8.10(\mathrm{~d}, 7.2)$ \\
\hline \multirow{7}{*}{ Leu-4 } & 1 & 171.7 & - \\
\hline & 2 & 50.6 & $4.44(\mathrm{~m})$ \\
\hline & 3 & 41.3 & 1.38 \\
\hline & 4 & 24.2 & 1.48 \\
\hline & 5 & 23.0 & 0.77 \\
\hline & 6 & 21.6 & 0.82 \\
\hline & $\mathrm{NH}$ & & $7.66(\mathrm{~d}, 8.4)$ \\
\hline \multirow{6}{*}{ Val } & 1 & 170.7 & - \\
\hline & 2 & 57.4 & $4.05(\mathrm{~m})$ \\
\hline & 3 & 29.4 & $2.03(\mathrm{~m})$ \\
\hline & 4 & 18.1 & $0.80(\mathrm{~m})$ \\
\hline & 5 & 19.2 & $0.81(\mathrm{~m})$ \\
\hline & $\mathrm{NH}$ & & $8.14(\mathrm{~m})$ \\
\hline \multirow{11}{*}{$\begin{array}{l}\text { Fatty acid } \\
\text { (anteiso-) }\end{array}$} & $1^{\prime}$ & 169.6 & - \\
\hline & 2 ' & 40.6 & $2.38(\mathrm{~m})$ \\
\hline & $3^{\prime}$ & 71.6 & $4.97(\mathrm{~m})$ \\
\hline & 4 ' & 33.3 & $1.50(\mathrm{~m})$ \\
\hline & 5 , & 24.1 & $1.17(\mathrm{~m})$ \\
\hline & $6^{\prime}-10^{\prime}$ & $28.6-29.3$ & $1.18(\mathrm{~m})$ \\
\hline & $11^{\prime}$ & 36.0 & $1.02 / 1.20(\mathrm{~m})$ \\
\hline & $12^{\prime}$ & 33.7 & $1.23(\mathrm{~m})$ \\
\hline & $13^{\prime}$ & 26.5 & $1.18(\mathrm{~m})$ \\
\hline & $14^{\prime}$ & 11.2 & $0.79(\mathrm{~m})$ \\
\hline & $15^{\prime}$ & 19.2 & $0.83(\mathrm{~m})$ \\
\hline
\end{tabular}

Glu: glutamic acid; Leu: leucine; Asp: aspartic acid; Val: valine. 


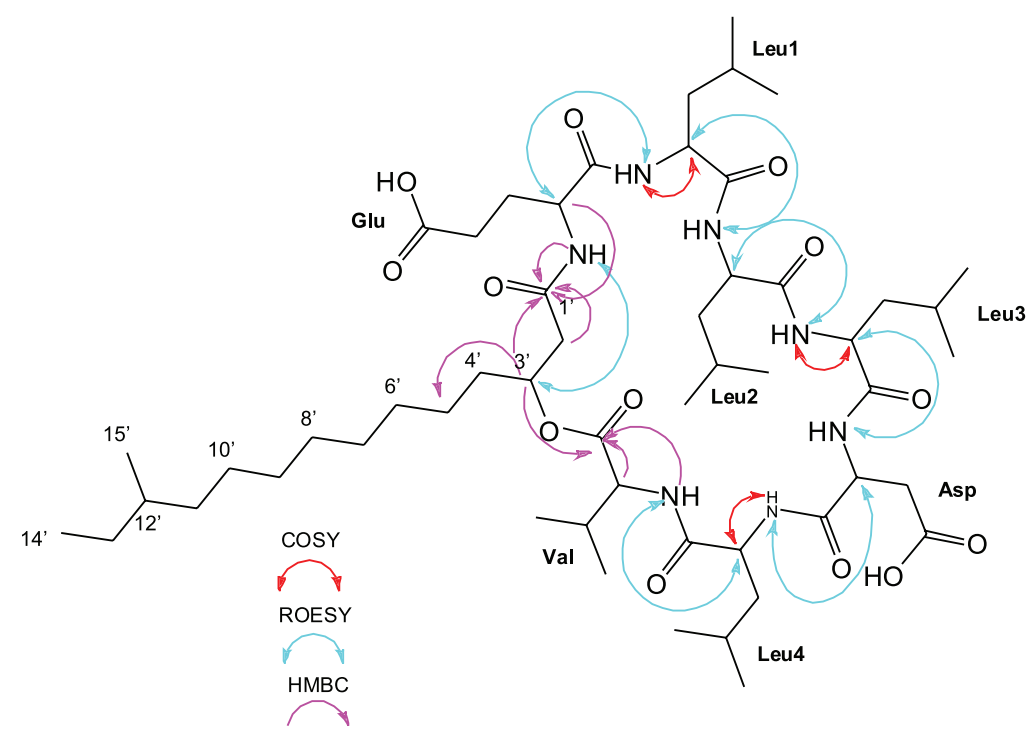

Figure 2. Selected HMBC, COSY and ROESY correlations of $\mathbf{1 .}$

Table 2. ${ }^{1} \mathrm{H}$ and ${ }^{13} \mathrm{C}$ NMR data for pumilacidin A (2) in $600 \mathrm{MHz}$, DMSO- $d_{6}$

\begin{tabular}{|c|c|c|c|}
\hline Position & No. & $\delta_{\mathrm{C}} / \mathrm{ppm}$ & $\delta_{\mathrm{H}} / \mathrm{ppm}$ (mult., $\left.J / \mathrm{Hz}\right)$ \\
\hline \multirow{7}{*}{ Glu } & 1 & 171.1 & - \\
\hline & 2 & 52.0 & $4.14(\mathrm{~m})$ \\
\hline & 3 & 27.4 & $1.71 / 1.87(\mathrm{~m})$ \\
\hline & 4 & 29.9 & $2.17(\mathrm{t}, 7.8)$ \\
\hline & 5 & 174.0 & - \\
\hline & $\mathrm{NH}$ & & $7.86(\mathrm{~d}, 6.6)$ \\
\hline & $-\mathrm{OH}$ & & \\
\hline \multirow{7}{*}{ Leu-1 } & 1 & 172.1 & - \\
\hline & 2 & 52.1 & $4.12(\mathrm{~m})$ \\
\hline & 3 & 38.5 & $1.42(\mathrm{~m})$ \\
\hline & 4 & 23.9 & $1.46(\mathrm{~m})$ \\
\hline & 5 & 23.0 & $0.78(\mathrm{~m})$ \\
\hline & 6 & 22.5 & $0.78(\mathrm{~m})$ \\
\hline & $\mathrm{NH}$ & & $7.97(\mathrm{bs})$ \\
\hline \multirow{7}{*}{ Leu-2 } & 1 & 172.1 & - \\
\hline & 2 & 51.7 & $4.08(\mathrm{~m})$ \\
\hline & 3 & 39.7 & $1.46(\mathrm{~m})$ \\
\hline & 4 & 24.2 & $1.51(\mathrm{~m})$ \\
\hline & 5 & 23.0 & $0.82(\mathrm{~m})$ \\
\hline & 6 & 22.7 & $0.82(\mathrm{~m})$ \\
\hline & $\mathrm{NH}$ & & $8.19(\mathrm{~d}, 6.0)$ \\
\hline \multirow{7}{*}{ Leu-3 } & 1 & 171.6 & - \\
\hline & 2 & 51.3 & $4.22(\mathrm{~m})$ \\
\hline & 3 & 40.8 & $1.39(\mathrm{~m})$ \\
\hline & 4 & 234.0 & $1.53(\mathrm{~m})$ \\
\hline & 5 & 21.8 & $0.75(\mathrm{~m})$ \\
\hline & 6 & 23.0 & $0.83(\mathrm{~m})$ \\
\hline & $\mathrm{NH}$ & & $7.98(\mathrm{bs})$ \\
\hline
\end{tabular}

\begin{tabular}{|c|c|c|c|}
\hline Position & No. & $\delta_{\mathrm{C}} / \mathrm{ppm}$ & $\delta_{\mathrm{H}} / \mathrm{ppm}$ (mult., $J / \mathrm{Hz}$ ) \\
\hline \multirow{5}{*}{ Asp } & 1 & 170.0 & - \\
\hline & 2 & 49.7 & $4.45(\mathrm{~m})$ \\
\hline & 3 & 36.1 & $\begin{array}{c}2.64(\mathrm{dd}, 4.8 .17 .4) / 2.56(\mathrm{dd}, 9.0 . \\
16.2)\end{array}$ \\
\hline & 4 & 171.7 & - \\
\hline & $\mathrm{NH}$ & & $8.10(\mathrm{~d}, 7.2)$ \\
\hline \multirow{7}{*}{ Leu-4 } & 1 & 171.8 & - \\
\hline & 2 & 50.5 & $4.44(\mathrm{~m})$ \\
\hline & 3 & 41.3 & 1.39 \\
\hline & 4 & 24.4 & 1.47 \\
\hline & 5 & 23.0 & 0.82 \\
\hline & 6 & 22.5 & 0.82 \\
\hline & $\mathrm{NH}$ & & $7.66(\mathrm{~d}, 8.4)$ \\
\hline \multirow{7}{*}{ Ile } & 1 & 170.7 & - \\
\hline & 2 & 56.5 & $4.10(\mathrm{~m})$ \\
\hline & 3 & 35.8 & $1.79(\mathrm{~m})$ \\
\hline & 4 & 24.6 & $1.25(\mathrm{~m})$ \\
\hline & 5 & 11.2 & $0.76(\mathrm{~m})$ \\
\hline & 6 & 15.5 & $0.79(\mathrm{~m})$ \\
\hline & $\mathrm{NH}$ & & $8.14(\mathrm{~d}, 7.8)$ \\
\hline \multirow{11}{*}{$\begin{array}{l}\text { Fatty acid } \\
\text { (anteiso-) }\end{array}$} & $1^{\prime}$ & 169.5 & - \\
\hline & $2^{\prime}$ & 40.8 & $2.38(\mathrm{~m})$ \\
\hline & $3^{\prime}$ & 71.7 & $4.95(\mathrm{~m})$ \\
\hline & $4^{\prime}$ & 33.3 & $1.52(\mathrm{~m})$ \\
\hline & 5 & 24.2 & $1.17(\mathrm{~m})$ \\
\hline & $6^{\prime}-10^{\prime}$ & $28.9-29.4$ & $1.16(\mathrm{~m})$ \\
\hline & $11^{\prime}$ & 36.0 & $1.00 / 1.21(\mathrm{~m})$ \\
\hline & $12^{\prime}$ & 33.8 & $1.21(\mathrm{~m})$ \\
\hline & $13^{\prime}$ & 26.5 & $1.18(\mathrm{~m})$ \\
\hline & $14^{\prime}$ & 11.2 & $0.77(\mathrm{~m})$ \\
\hline & $15^{\prime}$ & 19.1 & $0.76(\mathrm{~m})$ \\
\hline
\end{tabular}

Glu: glutamic acid; Leu: leucine; Asp: aspartic acid; Ile: isoleucine. 
Glu-Leu1-Leu2-Leu3-Asp-Leu4-Ile and a $\beta$-amino fatty acid chain (Table 2).

The ESITOFHRMS spectra was concordant with the proposed structure, presenting a pseudo-molecular ion peak $\mathrm{m} / z$ 1072.6896 [M+ Na $]^{+}$(calcd. for $\mathrm{C}_{54} \mathrm{H}_{95} \mathrm{~N}_{7} \mathrm{O}_{13} \mathrm{Na}$, 1072.6886). From these data, and comparison of NMR data (in DMSO- $d_{6}$ ) with those reported (in $\mathrm{CD}_{3} \mathrm{OD}$ ), ${ }^{20}$ compound $\mathbf{2}$ was identified as pumilacidin A.

The compounds 3,4 and 5 were identified by comparison with data reported in the literature as the pumilacidins $\mathrm{E}$, $\mathrm{D}$ and $\mathrm{C}$, respectively. ${ }^{10-12}$ The absolute configurations of all amino acids units in pumilacidins A-E isolated in this work were assigned as L-, L-, D-, L-, L-, D and L- from N to $\mathrm{C}$-terminal based on the obtained optical rotation values in comparison with those of literature. ${ }^{10}$

Pumilacidins display a broad spectrum of biological activities, such as antiviral activity against herpes simplex virus type 1 , antiulcer activity, ${ }^{10}$ antifungal activity, ${ }^{12}$ antibacterial activity against Staphylococcus aureus and S. epidermis, ${ }^{14,21}$ cell lysis..$^{16}$ Recently it was demonstrated that pumilacidins $\mathrm{A}$ and $\mathrm{C}$ inhibit the growth of malarial parasites in vitro. ${ }^{20}$ In this work, the antimicrobial activity of all isolated compounds was evaluated against Pseudomonas aeruginosa, Escherichia coli, methicillin resistant Staphylococcus aureus, Bacillus subtilis and Candida albicans, but none of them showed antimicrobial activity at the maximum concentration tested $\left(1000 \mu \mathrm{gL}^{-1}\right)$.

\section{Conclusions}

In summary, a series of cyclic lipopeptides were isolated from the solid culture of the marine-derived bacterium Bacillus sp. 4040. The structures of $\mathbf{1 - 5}$ were determined using a combination of mass spectrometry, NMR spectroscopy and/or comparison with data from the literature. The ${ }^{1} \mathrm{H}$ and ${ }^{13} \mathrm{C}$ NMR data of $\mathbf{1}$ is being described here for the first time. All compounds were evaluated against five microorganisms, but antimicrobial activity was not detected, and this result is in accordance with Naruse et al. ${ }^{10}$ Although the bacterium under study has not been identified at the species level, the identification of pumilacidins almost exclusively to the species Bacillus pumilus suggests that these substances may be the chemical markers of this species, and that the bacteria being studied is probably $B$. pumilus.

\section{Supplementary Information}

Supplementary data $\left({ }^{1} \mathrm{H}\right.$ and ${ }^{13} \mathrm{C}$ NMR spectra and mass spectra) are available free of charge at http://jbcs.sbq.org.br as PDF file.

\section{Acknowledgments}

The authors thank Mike Leblanc for technical assistance and NSERC (Natural Sciences and Engineering Research Council of Canada) for funding.

\section{References}

1. Public Health England; Identification of Bacillus species; UK Standards for Microbiology Investigations: London, 2018, available at https://assets.publishing.service.gov. uk/government/uploads/system/uploads/attachment_data/ file/697260/ID_9i3.1.pdf, accessed in July 2019.

2. Sansinenea, E.; Ortiz, A.; Biotechnol. Lett. 2011, 33, 1523.

3. Beric, T.; Kojic, M.; Stankovic, S.; Topisirovic, L.; Degrassi, G.; Myers, M.; Venturi, V.; Fira, D.; Food Technol. Biotechnol. 2012, 50, 25.

4. Mondol, M. A. M.; Shin, H. J.; Islam, M. T.; Mar. Drugs 2013, $11,2846$.

5. Phyo, Y. Z.; Ribeiro, J.; Fernandes, C.; Kijjoa, A.; Pinto, M. M. M.; Molecules 2018, 23, 306.

6. Meena, K. R.; Kanwar, S. S.; BioMed Res. Int. 2015, 25, 473050.

7. Son, S.; Ko, S.-K.; Jang, M.; Kim, J. W.; Kim, G. S.; Lee, J. K.; Jeon, E. S.; Futamura, Y.; Ryoo, I.-J.; Lee, J.-S.; Oh, H.; Hong, Y.-S.; Kim, B. Y.; Takahashi, S.; Osada, H.; Jang, J.-H.; Ahn, J. S.; Mar. Drugs 2016, 14, 72.

8. Tareq, F. S.; Lee, M. A.; Lee, H.-S.; Lee, J.-S.; Lee, Y.-J.; Shin, H. J.; Mar. Drugs 2014, 12, 871.

9. Zhao, H.; Shao, D.; Jiang, C.; Shi, J.; Li, Q.; Huang, Q.; Rajoka, M. S. R.; Yang, H.; Jin, M.; Appl. Microbiol. Biotechnol. 2017, 101, 5951.

10. Naruse, N.; Tenmyo, O.; Kobaru, S.; Kamei, H.; Miyaki, T.; Konishi, M.; Oki, T.; J. Antibiot. 1990, 43, 267.

11. Tang, J.-S.; Gao, H.; Hong, K.; Yu, Y.; Jiang, M.-M.; Lin, H.-P.; Ye, W.-C.; Yao, X.-S.; Magn. Reson. Chem. 2007, 45, 792.

12. Melo, F. M. P.; Fiore, M. F.; Moraes, L. A. B.; Silva-Stenico, M. E.; Scramin, S.; Teixeira, M. A.; Melo, I. S.; Sci. Agric. 2009, 66, 583.

13. Kalinovskaya, N. I.; Kuznetsova, T. A.; Ivanova, E. P.; Romanenko, L. A.; Voinov, V. G.; Huth, F.; Laatsch, H.; Mar. Biotechnol. 2002, 4, 179.

14. Pabel, C. T.; Vater, J.; Wilde, C.; Franke, P.; Hofemeister, J.; Adler, B.; Bringmann, G.; Hacker, J.; Hentschel, U.; Mar. Biotechnol. 2003, 5, 424.

15. From, C.; Hormazabal, V.; Granum, P. E.; Int. J. Food Microbiol. 2007, 115, 319.

16. Brack, C.; Mikolasch, A.; Schlueter, R.; Otto, A.; Becher, D.; Wegner, U.; Albrecht, D.; Riedel, K.; Schauer, F.; Mar. Biotechnol. 2015, 17, 290.

17. Dalisay, D. S.; Williams, D. E.; Wang, X. L.; Centko, R.; Chen, J.; Andersen, R. J.; PLoS One 2013, 8, e77078. 
18. http://blast.ncbi.nlm.nih.gov/Blast.cgi, accessed in July 2019.

19. https://www.ncbi.nlm.nih.gov/nuccore/KY476210.1, accessed in August 2019.

20. Torres-Mendoza, D.; Coronado, L. M.; Pineda, L. M.; Guzmán, H. M.; Dorrestein, P. C.; Spadafora, C.; Gutiérrez, M.; Molecules 2018, 23, 2179.
21. Saggase, A.; Culurciello, R.; Casillo, A.; Corsaro, M. M.; Ricca, E.; Baccigalupi, L.; Mar. Drugs 2018, 16, 180.

Submitted: December 15, 2018

Published online: August 9, 2019 